\title{
ANALISIS FAKTOR FUNDAMENTAL TERHADAP EXCESS RETURN SAHAM SYARIAH PERUSAHAAN JAKARTA ISLAMIC INDEX
}

\author{
Azwar, Indo Yama, Arief Mufraini, \\ Suhendra, \& Sihabudin Noor ${ }^{*}$
}

\begin{abstract}
Fundamental Factor Analysis of the Company's Islamic Excess Stock Return in Jakarta Islamic Index. The study concluded that based on the results of testing by using multiple regression analysis, there are four variables that significantly affect the excess return variables, they are: $\mathrm{BV}$, DER, ROE and SWBI. Besides, they are other variables such as PER, nflation, and exchange rate had no significant effect on the variable excess stock returns. Thus, it can be assumed that the JII firms during the study period was fulfilling aspects of sharia compliance. The indications are book value can represent the real value of the assets of the company itself and the highest ratio of debt to asset is $2.84 \%$. meanwhile, the highest determination of Islamic National Council is 33\%.
\end{abstract}

Keywords: fundamental factors, excess return, stock

Abstrak: Analisis Faktor Fundamental terhadap Excess Return Saham Syariat Perusahaan Jakarta Islamic Index. Penelitian ini menyimpulkan bahwa berdasarkan hasil pengujian dengan menggunakan analisis regresi berganda terdapat empat variabel yang secara signifikan berpengaruh terhadap variabel excess return, yaitu: BV, DER, ROE, dan SWBI. Sedangkan tiga variabel lainnya, yaitu: PER, inflasi, dan kurs tidak berpengaruh signifikan terhadap variabel excess return saham. Dengan demikian, dapat diasumsikan bahwa perusahaan-perusahaan JII selama periode penelitian ini sudah memenuhi aspek kepatuhan syariah. Indikasinya antara lain: book value mampu merepresentasikan nilai riil aset perusahaan itu sendiri dan rasio utang terhadap aset paling tinggi 2,84\%, sedangkan ketetapan Dewan Syariah Nasional paling tinggi adalah $33 \%$.

Kata Kunci: faktor fundamental, excess return, saham

Naskah diterima: 9 Agustus 2010, direvisi: 27 November 2010, disetujui: 9 Desember 2010.

* Fakultas Ekonomi Bisnis UIN Syarif Hidayatullah. Jl. Ir. H. Juanda No.95, Ciputat, Jakarta. Email: arif.mufraini@yahoo.com 


\section{Pendahuluan}

Perkembangan pasar modal syariah di Indonesia, secara umum ditandai oleh pelbagai indikator di antaranya adalah semakin maraknya para pelaku pasar modal syariah yang mengeluarkan efek-efek syariah yaitu saham-saham yang tergabung dalam Jakarta Islamic Indeks (JII). Jakarta Islamic Indeks (JII) yang dikeluarkan oleh BEJ merupakan indeks dari 30 saham perusahaan yang kegiatannya dipandang tidak bertentangan dengan syariah dan dievaluasi setiap enam bulan.

Jakarta Islamic Index dimaksudkan untuk digunakan sebagai tolok ukur (benchmark) untuk mengukur kinerja suatu investasi pada saham dengan basis syariah. Melalui index ini diharapkan dapat meningkatkan kepercayaan investor untuk mengembangkan investasi dalam ekuiti secara syariah. Jakarta Islamic Index terdiri atas 30 jenis saham yang dipilih dari saham-saham yang sesuai dengan syariah Islam. Penentuan kriteria pemilihan saham dalam Jakarta Islamic Index melibatkan pihak Dewan Pengawas Syariah PT. Danareksa Invesment Management.

Saham-saham yang masuk dalam indeks syariah adalah emiten yang kegiatan usahanya tidak bertentangan dengan syariah seperti usaha perjudian dan permainan yang tergolong judi atau perdagangan yang dilarang, usaha lembaga keuangan konvensional (ribawî) termasuk perbankan dan asuransi konvensional, usaha yang memproduksi, mendistribusi serta memperdagangkan makanan dan minuman yang tergolong haram, usaha yang memproduksi, mendistribusi dan/atau menyediakan barang-barang ataupun jasa yang merusak moral dan bersifat mudarat.

Pengkajian ulang akan dilakukan enam bulan sekali dengan penentuan komponen index pada awal bulan Januari dan Juli setiap tahunnya. Sedangkan perubahan pada jenis usaha emiten akan dimonitoring secara terus menerus berdasarkan data-data publik yang tersedia. Nilai nominal saham saat penerbitan adalah nilai yang dibayarkan oleh investor untuk memiliki bagian dari kepemilikan perusahaan. Nilai yang dibayar oleh investor harus sama dengan nilai nominal saham (par value). Akad transaksi penerbitan saham syariah berbasis kepada prinsip transaksi syirkah atau perkongsian.

Konsep yang dipakai dalam hal pembagian keuntungan dan tanggung jawab adalah:

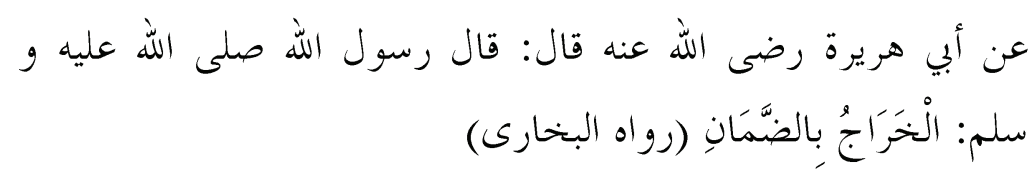


Keuntungan harus diikuti oleh tanggung jawab atau risiko. (H.r. al-Bukhârî)

Atau dalam bahasa kaidah fiqhiyyah disebutkan bahwa potensi keuntungan harus diiringi oleh potensi kerugian, sebagai berikut: ${ }^{1}$

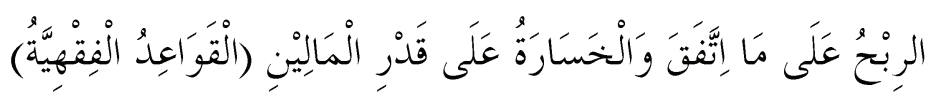

Keuntungan dibagi sesuai kesepakatan, sedang kerugian dibagi berdasarkan besaran modal dari pihak-pihak terkait.

Dengan begitu, keuntungan dapat dibagikan sesuai dengan kesepakatan ('an tarâdhin) tetapi kerugian harus berdasarkan kontribusi saham masingmasing investor.

Bagi investor, ketidakpastian memperoleh return inilah yang didefinisikan sebagai risiko investasi di pasar modal. Lintner (1968) serta Miller dan Scholes (1972) secara terpisah berhasil merumuskan model keseimbangan umum antara return dan risiko yang hampir sama. Model tersebut dikenal dengan nama capital asset pricing model (CAPM). Menurut CAPM, satu-satunya risiko yang patut dipertimbangkan dalam menjelaskan return adalah beta (risiko sistematik). Pengaruh beta terhadap return tersebut adalah positif. Model CAPM ini menggunakan mean variance efficient dalam konteks Markowitz, yang telah banyak digunakan, baik di kalangan akademisi maupun praktisi. Akan tetapi, pada studi empiris terjadi pelbagai kontradiksi pada model CAPM.

Kontradiksi tersebut karena adanya fakta-fakta yang menunjukkan bahwa ada faktor-faktor lain selain beta seperti: size (kapitalisasi pasar saham [ME]), leverage (Debt to Equity ratio, DER), rasio book equity terhadap market equity, $\mathrm{BE} / \mathrm{ME}$ (kebalikannya adalah price to book value, $\mathrm{PBV}$ ), rasio pendapatan/harga (earning/price ratio, E/P) yang berperan besar dalam menjelaskan pergerakan harga saham perusahaan.

Penelitian mengenai analisis expected return serta faktor yang memengaruhinya telah dilakukan oleh Suhadak (2005). Sampel dalam penelitian ini dikelompokkan menjadi sembilan kelompok industri yang go publik di BEJ pada periode 1996-2000. Variabel independen yang digunakan terdiri atas fundamental mikro yang terdiri atas: DPR, growth, leverage, liquidity, asset size, dan variability of earning, dan fundamental makro yang terdiri atas: inflasi, suku bunga, nilai

${ }^{1}$ Al-Nadwâ, al-Qawâ'id al-Fiqhiyyah, (Bayrût: Dâr el-Qalâm, 1998), h. 113. 
tukar mata uang dan GDP. Variabel dependen dalam penelitian ini adalah risiko pasar dan expected return. Hasil pengujian menunjukkan bahwa pada hipotesis satu faktor fundamental mikro berpengaruh negatif terhadap risiko pasar adalah terbukti. Hipotesis dua, yaitu faktor fundamental mikro berpengaruh positif terhadap expected return adalah terbukti karena menunjukkan nilai yang positif. Hipotesis tiga, yaitu faktor fundamental makro berpengaruh positif terhadap risiko pasar hasilnya terbukti karena menunjukkan nilai positif. Hipotesis empat, yaitu faktor fundamental makro berpengaruh negatif terhadap expected return hasil-nya tidak terbukti. Hipotesis lima, yaitu faktor fundamental mikro dan makro berpengaruh terhadap risiko pasar, hasilnya adalah terbukti. Hipotesis enam, yaitu faktor fundamental mikro dan makro berpengaruh terhadap expected return hasilnya tidak terbukti. Hipotesis tujuh, yaitu di antara faktor fundamental mikro yakni DPR dan diantara faktor fundamental makro yakni inflasi mempunyai pengaruh paling dominan terhadap risiko pasar dan expected return adalah terbukti. Hipotesis delapan, yaitu risiko pasar berpengaruh positif terhadap expected return hasilnya tidak terbukti. ${ }^{2}$

Penelitian terakhir dilakukan oleh Sulastri (1999) terhadap perbedaan risiko saham di bursa-bursa saham negara Asia antara periode krisis dan sebelumnya yang juga menggunakan standar CAPM. Hasilnya adalah terdapat variasi pada beberapa bursa tersebut, khususnya di negara Indonesia yang diambil dari saham yang terdaftar pada Jakarta Stock Exchange. Hasil penelitian menunjukan bahwa terdapat perbedaan risiko yang signifikan bagi pemodal asing antara periode krisis dan sebelumnya, sedang bagi pemodal domestik ada perbedaan risiko tetapi tidak signifikan secara statistik. Perbedaan tersebut disebabkan risiko saham pada masa krisis adalah lebih besar.

Karena faktor-faktor yang memengaruhi harga saham sangatlah banyak, maka untuk melakukan analisis, diperlukan beberapa tahapan analisis. Tahapan yang dilakukan diawali dengan analisis dari: Pertama, kondisi makro ekonomi atau kondisi pasar. Kedua, analisis industri. Ketiga, analisis kondisi spesifik perusahaan.

Berdasarkan uraian di atas, maka masalah yang akan diteliti dan dibahas melalui penelitian ini adalah untuk melihat sekaligus menganalisis faktor-faktor fundamental yang signifikan memengaruhi pergerakan harga saham perusahaan kelompok Jakarta Islamic Index (JII). Oleh karena itu, maka tujuan penelitian adalah untuk menganalisis apakah terdapat pengaruh faktor fundamental price earning ratio (PER), book value (BV), debt to equity ratio (DER), return on equity

${ }^{2}$ Suhadak, Analisis Expected Return serta Faktor yang Memengaruhinya, (Jakarta: Arthavidya, Tahun 6 No.1, 2005), h. 41. 
(ROE), tingkat sertifikat wadiah bank indonesia (SWBI), tingkat inflasi dan kurs terhadap excess return (saham) perusahaan baik secara parsial maupun simultan.

\section{Metodologi}

Penelitian ini dilakukan untuk menguji apakah terdapat pengaruh faktor fundamental price earning ratio (PER), book value (BV), debt to equity ratio (DER), return on equity (ROE), tingkat SWBI, tingkat inflasi dan kurs terhadap excess return perusahaan perusahaan yang termasuk dalam Jakarta Islamic Index sejak tahun 2004 sampai dengan tahun 2006. Adapun kriteria dalam pemilihan sampel adalah perusahaan yang terdaftar dalam Jakarta Islamic Indeks secara terus menerus sejak tahun 2004 sampai dengan tahun 2006 dan perusahaan tersebut mengeluarkan data atau laporan keuangan perusahaan per quarter dari tahun 2004 sampai dengan tahun 2006.

Berdasarkan data tersebut maka perusahaan yang selalu masuk dalam daftar Jakarta Islamic Indeks periode Februari 2004 sampai Februari 2006 terdapat enam perusahaan, yaitu: Aneka Tambang, Indofood, Indosat, Timah, United Tractor, dan Telkom.

Untuk menggunakan statistik parametrik harus diuji terlebih dahulu datanya. Asumsi utama yang harus dipenuhi adalah data yang akan dianalisis berdistribusi normal. Selain itu dalam regresi harus dipenuhi asumsi linieritas. Kemudian juga akan dilakukan pengujian persyaratan lainnya seperti uji multikolinieritas, heteroskedastisitas, dan autokorelasi. Model regresi yang baik adalah bahwa hubungan antara variabel independen dengan variabel dependen bersifat linear, tidak terjadi multikolinieritas antar variabel independen, heteroskedastisitas (ketidaksamaan varians dari residual satu pengamatan ke pengamatan yang lain) dan autokorelasi (korelasi antara sesama urutan pengamatan dari waktu ke waktu). Oleh karenanya diperlukan pengujian dan pembersihan terhadap pelanggaran asumsi dasar, jika memang terjadi.

\section{Model Regresi Berganda}

Untuk melihat pengaruh variabel independen terhadap variabel dependen digunakan model persamaan regresi berganda sebagai berikut:

$$
Y=a+b_{1} X_{1}+b_{2} X_{2}+b_{3} X_{3}+b_{4} X_{4}+b_{5} X_{5}+b_{6} X_{6}+b_{7} X_{7}+\varepsilon_{i}
$$

dimana :

$\mathrm{Y} \quad=$ Excess Return

$\mathrm{X}_{1} \quad=$ Price Earning Ratio (PER) 


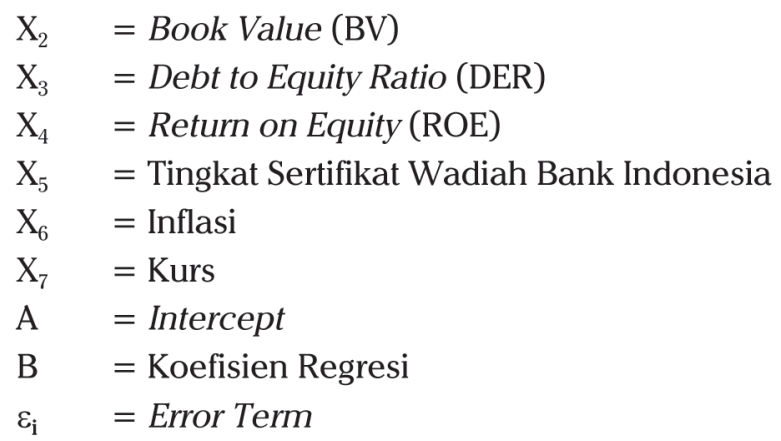

\section{Menilai Ketepatan (Goodness of Fit) dari Model}

Ketepatan fungsi regresi sampel dalam menaksir nilai aktual dapat diukur dari goodness of fit-nya. Secara statistik, dapat diukur dari nilai statistik-t ( $t$-test), nilai statistik-F (F-test) dan $\mathrm{R}^{2} /$ Adjusted $\mathrm{R}^{2}$.

\section{Pengaruh PER, BV, DER, ROE, Tingkat SWBI, Tingkat Inflasi dan Kurs terhadap Excess Return Secara Parsial}

Berdasarkan tabel 3.1. diperoleh hasil t-hitung untuk price eraning ratio (PER) sebesar -1,629 dan nilai t-tabel dengan alpha 5\% dan df 71 sebesar 1,991. Karena pengujian pihak kiri ini berarti t-hitung lebih besar dari pada t-tabel ($1,629>-1,991)$. Selanjutnya dilihat dari probabilitas signifikansi diperoleh hasil sebesar 0,108 lebih besar daripada $0,05(0,108>0,05)$. Sehingga hipotesis nol $\left(\mathrm{H}_{0}\right)$ diterima dan menolak hipotesis alternatif $\left(\mathrm{H}_{\mathrm{a}}\right)$. Artinya bahwa tidak terdapat pengaruh yang signifikan antara variabel price eraning ratio (PER) terhadap variabel excess return. Berdasarkan uji statistik-t ini, dapat disimpulkan bahwa hipotesis yang menyatakan bahwa price eraning ratio (PER) secara individual (sendiri-sendiri) memiliki pengaruh yang signifikan terhadap excess return tidak dapat dibuktikan.

Selanjutnya pengaruh variabel book value (BV) terhadap excess return. Hasil t-hitung sebesar -2,284. Ini berarti t-hitung lebih kecil daripada t-tabel ($2,284<-1,991)$. Selanjutnya dilihat dari probabilitas signifikansi diperoleh hasil sebesar 0,026 lebih kecil daripada $0,05(0,026<0,05)$. Sehingga hipotesis nol $\left(\mathrm{H}_{0}\right)$ ditolak dan hipotesis alternatif $\left(\mathrm{H}_{\mathrm{a}}\right)$ diterima karena terdapat bukti yang kuat untuk menolak hipotesis nol $\left(\mathrm{H}_{0}\right)$. Artinya bahwa terdapat pengaruh yang signifikan antara variabel book value (BV) terhadap excess return. Berdasarkan uji statistik-t ini, dapat disimpulkan bahwa hipotesis yang menyatakan variabel book value (BV) secara individual (sendiri-sendiri) memiliki pengaruh yang signifikan terhadap excess return dapat dibuktikan. 
Pengaruh variabel debt to equity ratio (DER) terhadap excess return diperoleh hasil t-hitung sebesar -1,789. Ini berarti t-hitung lebih besar daripada ttabel $(-1,789>-1,991)$. Selanjutnya dilihat dari probabilitas signifikansi diperoleh hasil sebesar 0,078 lebih besar daripada 0,05 (0,078>0,05). Sehingga hipotesis nol $\left(\mathrm{H}_{0}\right)$ diterima dan hipotesis alternatif $\left(\mathrm{H}_{\mathrm{a}}\right)$ ditolak. Namun pada alpha $10 \%$ diperoleh nilai t-tabel sebesar 1,665. Ini berarti t-hitung lebih kecil daripada ttabel $(-1,789<-1,665)$. Selanjutnya dilihat dari probabilitas signifikansi diperoleh hasil sebesar 0,078 lebih kecil daripada $0,10(0,078<0,10)$. Artinya bahwa terdapat pengaruh yang signifikan antara variabel debt to equity ratio (DER) terhadap excess return. Berdasarkan uji statistik-t ini, dapat disimpulkan bahwa hipotesis yang menyatakan variabel debt to equity ratio (DER) secara individual (sendiri-sendiri) memiliki pengaruh yang signifikan terhadap excess return dapat dibuktikan.

Pengaruh variabel return on equity (ROE) terhadap excess return diperoleh hasil t-hitung sebesar -2,007. Ini berarti t-hitung lebih kecil daripada t-tabel $(-2,007$ $<-1,991)$. Selanjutnya dilihat dari probabilitas signifikansi diperoleh hasil sebesar 0,049 lebih kecil daripada $0,05(0,049<0,05)$. Sehingga hipotesis nol $\left(\mathrm{H}_{0}\right)$ ditolak dan hipotesis alternatif $\left(\mathrm{H}_{\mathrm{a}}\right)$ diterima. Ini Artinya bahwa terdapat pengaruh yang signifikan antara variabel return on equity (ROE) terhadap excess return. Berdasarkan uji statistik-t ini, dapat disimpulkan bahwa hipotesis yang menyatakan bahwa variabel return on equity (ROE) secara individual (sendiri-sendiri) memiliki pengaruh yang signifikan terhadap excess return dapat dibuktikan.

Tabel 3.1.

Hasil Output Regresi Pengaruh Variabel Independen terhadap Excess Return

Coefficients(a)

\begin{tabular}{|c|c|c|c|c|c|c|}
\hline \multirow[t]{2}{*}{ Model } & & \multicolumn{2}{|c|}{$\begin{array}{l}\text { Unstandardized } \\
\text { Coefficients }\end{array}$} & \multirow{2}{*}{$\begin{array}{c}\text { Standardized } \\
\text { Coefficients } \\
\text { Beta } \\
\end{array}$} & \multirow{2}{*}{$\begin{array}{l}\mathrm{T} \\
\mathrm{B}\end{array}$} & \multirow{2}{*}{$\begin{array}{c}\text { Sig. } \\
\text { Std. Error }\end{array}$} \\
\hline & & $\mathrm{B}$ & Std. Error & & & \\
\hline \multirow[t]{8}{*}{1} & (Constant) & .157 & .185 & & .848 & .400 \\
\hline & PER & -.002 & .001 & -.195 & -1.629 & .108 \\
\hline & BV & $-3.79 \mathrm{E}-005$ & .000 & -.534 & -2.284 & .026 \\
\hline & DER & -.046 & .026 & -.375 & -1.789 & .078 \\
\hline & ROE & -.180 & .090 & -.293 & -2.007 & .049 \\
\hline & SWBI & 34.639 & 7.352 & .523 & 4.712 & .000 \\
\hline & INFLASI & 2.193 & 1.698 & .177 & 1.291 & .201 \\
\hline & KURS & $-1.15 \mathrm{E}-005$ & .000 & -.072 & -.649 & .519 \\
\hline
\end{tabular}

a Dependent Variable: Exces_return

Sumber: data diolah, 2007 
Pengaruh variabel Sertifikat Wadiah Bank Indonesia (SWBI) terhadap excess return diperoleh hasil t-hitung untuk SWBI sebesar 4,712 dan nilai t-tabel dengan alpha 5\% dan df 71 sebesar 1,991. Ini berarti t-hitung lebih besar daripada t-tabel $(4,712>1,991)$. Selanjutnya dilihat dari probabilitas signifikansi diperoleh hasil sebesar 0,00 lebih kecil daripada 0,05 $(0,00<0,05)$. Sehingga hipotesis nol $\left(\mathrm{H}_{0}\right)$ ditolak dan menerima hipotesis alternatif $\left(\mathrm{H}_{\mathrm{a}}\right)$. Artinya bahwa terdapat pengaruh yang signifikan antara variabel Sertifikat Wadiah Bank Indonesia (SWBI) terhadap variabel excess return. Berdasarkan uji statistik-t ini, dapat disimpulkan bahwa hipotesis yang menyatakan Sertifikat Wadiah Bank Indonesia (SWBI) secara individual (sendiri-sendiri) memiliki pengaruh yang signifikan terhadap excess return dapat dibuktikan.

Pengaruh variabel inflasi terhadap excess return diperoleh hasil t-hitung untuk inflasi sebesar 1,291 dan nilai t-tabel dengan alpha 5\% dan df 71 sebesar 1,991. Ini berarti t-hitung lebih kecil daripada t-tabel $(1,291<1,991)$. Selanjutnya dilihat dari probabilitas signifikansi diperoleh hasil sebesar 0,201 lebih besar daripada $0,05(0,201>0,05)$. Sehingga hipotesis nol $\left(\mathrm{H}_{0}\right)$ diterima dan menolak hipotesis alternatif $\left(\mathrm{H}_{\mathrm{a}}\right)$. Artinya bahwa tidak terdapat pengaruh yang signifikan antara variabel inflasi terhadap variabel excess return. Berdasarkan uji statistik-t ini, dapat disimpulkan bahwa hipotesis yang menyatakan inflasi secara individual (sendiri-sendiri) memiliki pengaruh yang signifikan terhadap excess return tidak dapat dibuktikan.

Pengaruh variabel kurs terhadap excess return diperoleh hasil t-hitung untuk variabel kurs sebesar -0,649 dan nilai t-tabel dengan alpha 5\% dan df 71 sebesar -1,991. Ini berarti t-hitung lebih besar daripada t-tabel $(-0,649>-1,991)$. Selanjutnya dilihat dari probabilitas signifikansi diperoleh hasil sebesar 0,519 lebih besar daripada 0,05 $(0,519>0,05)$. Sehingga hipotesis nol $\left(\mathrm{H}_{0}\right)$ diterima dan menolak hipotesis alternatif $\left(\mathrm{H}_{\mathrm{a}}\right)$. Artinya bahwa tidak terdapat pengaruh yang signifikan antara variabel kurs terhadap variabel excess return. Berdasarkan uji statistik-t ini, dapat disimpulkan bahwa hipotesis yang menyatakan kurs secara individual (sendiri-sendiri) memiliki pengaruh yang signifikan terhadap excess return tidak dapat dibuktikan.

\section{Pengaruh PER, BV, DER, ROE, Tingkat SWBI, Tingkat Inflasi dan Kurs terhadap Excess Return Secara Simultan}

Hipotesis yang akan dibuktikan adalah terdapat pengaruh variabel price earning ratio (PER), book value ( $B V)$, debt to equity ratio $(D E R)$, return on equity (ROE), tingkat SWBI, tingkat inflasi dan kurs terhadap Excess Return secara simultan. Dari hasil uji Anova atau F-hitung pada tabel 3.2 diketahui bahwa nilai F 
hitung sebesar 4,091 dan F-tabel sebesar 2,121 untuk alpha 5\%, sehingga $\mathrm{F}$ hitung lebih besar daripada $\mathrm{F}$ tabel $(4,091>2,121)$ sehingga $\mathrm{H}_{0}$ ditolak dan menerima $\mathrm{H}_{\mathrm{A}}$. Ini mengindikasikan bahwa variabel price earning ratio (PER), book value $(B V)$, debt to equity ratio $(D E R)$, return on equity (ROE), tingkat SWBI, tingkat inflasi dan kurs berpengaruh terhadap Excess Return secara simultan. Sehingga hipotesis yang menyatakan bahwa terdapat pengaruh variabel independen price earning ratio (PER), book value ( $B V)$, debt to equity ratio $(D E R)$, return on equity (ROE), tingkat SWBI, tingkat inflasi dan kurs terhadap excess return secara simultan dapat dibuktikan.

Tabel 3.2.

Hasil Pengujian Statistik F (Anova)

\begin{tabular}{clrrrrrr}
\hline \multirow{2}{*}{ Model } & \multicolumn{9}{c}{ ANOVA(b) } & & & \\
\hline \multirow{2}{*}{1} & Sum of & Df & Mean Square & F & Sig. \\
\cline { 2 - 8 } & Regression & .095 & 7 & .014 & 4.091 & $.001(\mathrm{a})$ \\
\cline { 2 - 8 } & Residual & .212 & 64 & .003 & & \\
\cline { 2 - 8 } & Total & .306 & 71 & & & & \\
\hline
\end{tabular}

a Predictors: (Constant), KURS, BV, SWBI, PER, INFLASI, ROE, DER

b Dependent Variable: Exces_return

Sumber : data diolah, 2007

Bila dilihat dari nilai koefisien determinasinya sebagaimana yang terlihat dalam tabel 3.3 ternyata pengaruh variabel independen dalam menjelaskan perubahan variabel excess return relatif rendah, yaitu sebesar 0,309. Namun untuk jumlah variabel independen dua atau lebih sebaiknya digunakan adjusted $\mathrm{R}^{2}$ (Singgih Santoso, 2004: 167).

Berdasarkan nilai adjusted $\mathrm{R}^{2}$ diketahui bahwa kemampuan variabel independen untuk menjelaskan perubahan variabel excess return secara bersamasama adalah sebesar 23,4\%. Atau dapat juga dikatakan bahwa variabel price earning ratio (PER), book value ( $B V)$, debt to equity ratio (DER), return on equity (ROE), tingkat SWBI, tingkat inflasi dan kurs dapat menjelaskan variabel excess return sebesar 23,4\%. Sehingga dengan demikian bahwa variabel excess return dapat dijelaskan oleh variabel price earning ratio (PER), book value (BV), debt to equity ratio $(D E R)$, return on equity (ROE), SWBI, tingkat inflasi dan kurs sebesar $23,4 \%$ sedangkan $76,6 \%$ dijelaskan oleh variabel lain yang tidak diteliti, seperti harga minyak dunia, harga emas, kondisi politik dalam negeri dan lain-lain. 
Tabel 3.3.

Koefisien Korelasi, Determinasi dan Adjusted $\mathrm{R}^{2}$

Model Summary

\begin{tabular}{lrrrr}
\hline Model & R & R Square & Adjusted R Square & $\begin{array}{c}\text { Std. Error of the } \\
\text { Estimate }\end{array}$ \\
\hline 1 & $.556(\mathrm{a})$ & .309 & .234 & .05751224 \\
\hline
\end{tabular}

a Predictors: (Constant), KURS, BV, SWBI, PER, INFLASI, ROE, DER Sumber : data diolah, 2007

Dengan demikian dapat dikatakan meskipun secara simultan variabel independen price earning ratio (PER), book value $(B V)$, debt to equity ratio $(D E R)$, return on equity (ROE), tingkat SWBI, tingkat inflasi dan kurs berpengaruh terhadap excess return, namun pengaruh tersebut lemah karena kemampuan variabel tersebut dalam menjelaskan excess return relatif rendah.

Berdasarkan tabel di atas, maka dapat disusun persamaan regresi untuk penelitian ini sebagai berikut: $\mathrm{Y}=0,157-0,000379 \mathrm{BV}-0,046 \mathrm{DER}-0,180 \mathrm{ROE}+$ 34,64 SWBI.

Pembahasan ini ditujukan untuk membuktikan kebenaran hipotesis yang telah diajukan, dengan melakukan pengujian menggunakan metode regresi berganda. Dari metode tersebut didapatkan hasil yang memuaskan, dimana ada empat variabel yang secara parsial berpengaruh signifikan terhadap variabel dependen, keempat variabel tersebut adalah BV, DER, ROE dan SWBI sedangkan tiga variabel independen yang lainnya, yaitu PER, inflasi dan kurs tidak berpengaruh terhadap variabel dependen.

Berdasarkan tabel nilai adjusted $R$ square diproleh hasil yang rendah. Rendahnya nilai $R$ square kemungkinan disebabkan oleh beberapa hal. Pertama, ada variabel lain yang lebih memengaruhi variabel independen yang peneliti tidak masukkan dalam penelitian sebagai variabel bebas dalam model persamaan regresi. Kedua, tidak semua variabel bebas berpengaruh signifikan secara parsial terhadap variabel bebas, hanya empat variabel yang berpengaruh secara signifikan terhadap variabel bebas.

Pembahasan selanjutnya yaitu mengenai koefisien regresi. Nilai koefisien regresi untuk variabel independen BV adalah signifikan, artinya perubahan BV berpengaruh signifikan terhadap perubahan excess return perusahaan Jakarta Islamic Index (JII) selama periode penelitian. Nilai koefisien untuk BV adalah sebesar -0,000379. Artinya apabila variabel independen BV mengalami kenaikan atau penurunan sebesar 1 satuan akan mengakibatkan penurunan atau kenaikan excess return sebesar 0,000379. Fenomena empiris ini dapat diinterpretasikan 
bahwa dalam hal ini mekanisme jual beli saham pada JII sudah berlaku sesuai syariah (syariah compliance), dimana harga saham seharusnya merepresentasikan modal perusahaan. Konsep saham syariah menekankan bahwa harga saham sama dengan modal saham (+) keuntungan (-) kerugian (+) akumulasi keuntungan (-) akumulasi kerugian, yang kesemuanya dibagi dengan jumlah saham, maka seharusnya pada saham JII tidak terdapat selisih yang terlalu jauh antara harga pasar dan harga bukunya.

Dalam aturan Islam, penentuan harga saham berbeda dengan penentuan harga seperti yang terjadi pada saat ini, dimana harga saham ditentukan oleh kekuatan supply dan demand. Jika kita melihat balance sheet dari joint stock company, maka terlihat bahwa aset sama dengan modal saham ditambah dengan kewajiban. Aset tersebut merupakan representasi dari modal, dimana kewajiban diasumsikan sama dengan nol. Sehingga, sertifikat sahamnya memiliki nilai tertentu, dimana nilainya akan sama dengan nilai asetnya. Setiap harga saham yang di atas atau di bawah nilai asetnya, tidak menunjukkan kondisi sesungguhnya. Tetapi kekuatan pasar mampu membuat harga saham tersebut berada di atas/di bawah nilai asetnya. Dalam pandangan Islam, untuk mencegah terjadinya distorsi ini, harga saham harus sesuai dengan nilai intrinsiknya.

Sedangkan nilai koefisien regresi untuk variabel independen DER juga signifikan berpengaruh terhadap variabel independen, akan tetapi negatif dengan nilai sebesar $\quad-0,046$. Hal ini berarti bahwa apabila terjadi kenaikan atau penurunan terhadap variabel independen DER sebesar 1 satuan maka akan mengakibatkan penurunan atau kenaikan excess return sebesar 0,046. Hal ini berlaku karena sebagai akibat dari ketentuan screening prosess saham-saham pada pasar modal untuk dapat masuk dalam index JII. Dan sebagaimana diketahui bahwa DSN menetapkan nilai DER tidak boleh lebih dari 33\%. Ketentuan ini sudah merupakan standar internasional yang diaplikasikan pada semua institusi pasar modal syariah.

Dalam pembahasan desain besar keuangan Islam, fenomena empiris ini memberikan gambaran yang mengembirakan, dimana para investor kurang memperhatikan faktor fundamental Inflasi untuk menanamkan modalnya pada perusahaan yang tergabung dalam JII. Hal ini secara tidak langsung, pada tataran mikro, dapat dijadikan momentum dimana perhitungan discount factor return saham syariah untuk lepas dari pengaruh suku bunga dan inflasi. Kemudian pada tataran makro, dapat dibaca bahwa para investor JII cenderung lebih dipengaruhi oleh emosi keagamaan ketimbang perhitungan rupiah dari investasi yang dikembangkan mekanisme konvensional. 
Untuk variabel yang paling dominan berpengaruh terhadap excess return dalam penelitian ini adalah variabel SWBI. Sedangkan hasil penelitian Seno (2000) variabel harga saham masa lalu mempunyai pengaruh yang paling dominan terhadap harga saham. Erna (2002) variabel yang paling dominan berpengaruh terhadap harga saham adalah nilai tukar valuta asing. Dilain pihak, hasil empiris ini dapat menguatkan argumentasi dari desain besar pengembangan sistim keuangan Islam untuk menjadikan SWBI sebagai tolok ukur penentuan tingkat return investasi (cost of equity) pada struktur modal perusahaan emiten JII.

Dari semua hasil temuan yang peneliti dapatkan, dapat peneliti simpulkan bahwa keempat variabel yang berpengaruh signifikan dapat dijadikan indikator bagi para investor untuk menilai dan memprediksikan excess return perusahaan. Di samping itu, para investor dan para manajer perusahaan untuk bisa memperhatikan variabel SWBI, karena variabel tersebut mempunyai pengaruh yang paling dominan terhadap excess return.

\section{Penutup}

Berdasarkan hasil pengujian dengan menggunakan analisis regresi berganda secara parsial terdapat empat faktor yang secara signifikan berpengaruh terhadap variabel excess return, yaitu: BV, DER, ROE dan SWBI, sedangkan tiga variabel lainnya yaitu PER, inflasi dan kurs tidak berpengaruh signifikan terhadap variabel excess return saham. Hal ini dapat menjawab tujuan penelitian yang diajukan.

Variabel yang paling dominan memengaruhi harga saham adalah variabel SWBI dengan nilai koefisien sebesar 34,64. Berdasarkan nilai adjusted $\mathrm{R}^{2}$ diketahui bahwa kemampuan variabel independen untuk menjelaskan perubahan variabel excess return secara bersama-sama adalah sebesar $23,4 \%$. Atau dapat juga dikatakan bahwa variabel price earning ratio (PER), book value ( $B V$ ), debt to equity ratio (DER), return on equity (ROE), tingkat Sertifikat Wadiah Bank Indonesia (SWBI), tingkat inflasi dan kurs dapat menjelaskan variabel excess return sebesar $23,4 \%$. Sedangkan $76.6 \%$ dijelaskan oleh variabel lain yang tidak diteliti, misalkan faktor politik dalam negeri, harga emas, dan terutama sekali harga minyak dunia.

Dalam penelitian ini, faktor fundamental yang signifikan memengaruhi pergerakan harga saham di Jakarta Islamic Index adalah Book Value, Debt Equity Ratio, Return on Equity serta SWBI. Dengan demikian, dapat diasumsikan bahwa perusahaan-perusahaan JII selama periode penelitian ini sudah memenuhi aspek kepatuhan syariah. Indikasinya antara lain: Pertama, book value mampu 
merepresentasikan nilai ril aset perusahaan itu sendiri. Kedua, rasio utang terhadap aset paling tinggi 2,84\%, sedangkan ketetapan Dewan Syariah Nasional paling tinggi adalah $33 \%$. Ketiga, ROE perusahaan. []

\section{Pustaka Acuan}

\section{Buku:}

Achsien, Igghi H, Investasi Syariah di Pasar Modal: Menggagas Konsep dan Praktek Manajemen Portofolio Syariah, Jakarta: Gramedia, 2000.

Adiningsih, Sri, Harianto, Farid, Perangkat dan Tekhnik Analisis Investasi di Pasar Modal Indonesia, Jakarta: BEJ, 1998.

Agus Sartono, Manajemen Keuangan Teori dan Aplikasi, Yogyakarta: BPFE, 1996.

Astuti, Pudji, Pengaruh Pecking Order Theory, dan Kebijakan Makro Terhadap Pengambilan Keputusan Struktur Keuangan; Leverage Perusahaan Industri Go Public di BEJ Periode 1991-2001, Jakarta: Disertasi, Universitas Borobudur, 2005.

Bûthî, al-, Muhammad Sa'id Ramadhân, Dhawâbith al-Mashlahah fi al-Syarîah alIslâmiyyah, Bayrût: Muassasah Risâlah, 1998.

Davis, James L., The Cross-Section of Realize Stock Return: The Pre-COMPUSTAT Evidence, USA: Journal Of Finence 49, 1994, Desember.

Dwiyanti, Vonny, Wawasan Bursa Saham, Jakarta: Universitas Atma Jaya, 1999.

Fayyâdh, 'Athiyah, Sûq al-Awraq al-Mâliyah fi Nizhâm al-Fiqh al-Islâmî, Mesir: Dâr al-Nasyr li al-Jâmi'ât, 1998.

Fischer, Donald E, Ronald J Jordan, Security Analysis and Portofolio Management, New Jersey: Prentice-Hall, Inc., 1987.

Hamad, Nazyah, Qadhâyah Fiqhiyyah al-Mu'âshshirah fî al-Mâl wa al-Iqtishâdiyyah, (Bayrût: Dâr al-Qalam, 2001.

Husnan, Suad, Pasar Modal Indonesia Masih Efisienkah?: Pengamatan Selama tahun 1990, Manajemen dan Usahawan Indonesia, Juni, 1991.

Ibn al-Qayyim, Syamsuddin Abû 'Abdullah Muhammad Abû Bakar, "I'lâm alMuwaqi'in 'an Rabb al-Alamîn”, .Kairo: Maktabah Kuliyah al-Azhariyyah, 1968.

Kamâl, Yûsuf, Al-Islâm wa al-Madzâhib al-Iqtishâdiyyah al-Mu'âhirah", MansurahMesir: Dâr el-Wafa li al-Tabâ'ah wa al-Nasr wa al-Tauzî', 1990.

Khayat, al-, 'Abd al-'Azîz, Al-Syarîkah fî al-Syarîah al-Islâmiyyah wa al-Qânûn alWadh'î", Bayrût: Muassasah Risâlah, 1983.

Nabhânî, al-, Taqiyuddin, 2004, al-Nizhâm al-Iqtishâdî fî al-Islâm, Bayrût: Dâr elUmmah, 2004.

Nawâwî, al-, Imâm Abû Zakariyâ Yahyâ bin Syaraf, Raudhah al-Thâlibîn", Bayrût: Dâr al-Kutub al-'Ilmiyyah, tanpa tahun terbit. 
Salûsy, al-, Alî Ahmad, Al-Iqtishâd al-Islâmiyyah wa Qadhâyâ al-Fiqhiyyah alMu'âshir", Bayrût: Muassasah al-Rayyân li al-Tauzî wa al-Nasyr, 1997.

Suhadak, Analisis Expected Return Serta Faktor Yang Memengaruhinya, Jakarta: Arthavidya, 2005, tahun 6, no.1.

Usman, Muhammad, Pengaruh Dividen Payout Ratio, Return on Equity, Earning Growth Terhadap Price Earning Ratio Pada Perusahaan Perbankan, dalam Journal Ekoma, September, 2001.

Yarnest, Analisis Pengaruh Faktor Fundamental Terhadap Return Saham Perusahaan Food \& Beverage yang Listed di BEJ, dalam Jurnal Ekonomi, 2001, tahun 5, no. 2 .

\section{Artikel/Makalah:}

Anastasia, Njo, "Analisis Faktor Fundamental dan Risiko Sistematik Terhadap Harga Saham Properti di BEJ", Jakarta: Jurnal Akuntansi dan Keuangan, 2003 November, vol. 5, no. 2.

Ahmad, Ausaf, "Towards an Islamic Finacial Market", Jeddah: Paper, Islamic Development Bank, 1997.

Dualeh, Sulaiman Abdi, "Islamic Securitisation: Practical Aspects", Jenewa: Paper paper World Conference on Islamic Banking, 1998.

Fama, Eugene F., "Efficient Capital Market II", dalam Journal of Finance, 1991 December.

------------, "Efficient Capital Market: A Review of Theory and Empirical Works", dalam Journal of Finance, 1970, May.

------------, Jensen, Roll F., "The Adjustment of Stock Price to New Information", New York: International Economic Review, 1969, February.

Lestari, Murni \& Christianti, Ari, "Analisis Pengaruh Nilai Saham Yang Beredar, Struktur Modal, Risiko Pasar dan Suku Bunga Terhadap Return Saham di BEJ dengan Pendekatan Model Dinamis: Studi Kasus pada Sektor Aneka Industri Tahun 1996 - 2002", Jakarta: Jurnal Riset Akuntansi dan Keuangan, 2005, Vol.1 No.1. 